\title{
Synthesis of New Hybrid Derivatives from Metronidazole and Eugenol Analogues as Trypanocidal Agents
}

Mônica Fraccarolli Pelozo ${ }^{1}$, Giovanna Fiori Serpa Lima ${ }^{1}$, Cleydson Finotti Cordeiro ${ }^{1}$, Luana Sueli Silva ${ }^{2}$, Ivo Santana Caldas $^{2}$, Diogo Teixeira Carvalho ${ }^{1}$, Stefânia Neiva Lavorato ${ }^{3}$, Jamie Anthony Hawkes ${ }^{1}$, Lucas Lopardi Franco ${ }^{1}$

${ }^{1}$ Faculdade de Ciências Farmacêuticas, Universidade Federal de Alfenas, Brazil; ${ }^{2}$ Instituto de Ciências Biomédicas, Universidade Federal de Alfenas, Brazil; ${ }^{3}$ Centro de Ciências Biológicas e Saúde, Universidade Federal do Oeste da Bahia, Brazil

Corresponding author: Lucas Lopardi Franco, Faculdade de Ciências Farmacêuticas, Departamento de Alimentos e Medicamentos, Universidade Federal de Alfenas, Rua Gabriel Monteiro da Silva 700, Alfenas, MG, 37130-001, Brazil; email: lucas.franco@unifalmg.edu.br

Received, March 23, 2021; Revised July 3, 2021; Accepted, August 3, 2021; Published, August 18, 2021

\begin{abstract}
Background: The search for new drug compounds is always challenging and there are several different strategies that involve the most varied and creative approaches in medicinal chemistry. One of them is the technique of molecular hybridisation: forming a hybrid compound from two or more pharmacophoric subunits. These hybrids may maintain the characteristics of the original compound and preferably show improvements to its pharmacological action, with reduced side effects and lower toxicity when compared to the original components. This study specifically focuses on synthesising hybrid molecules which demonstrate trypanocidal activity against the epimastigote and trypomastigote forms of Trypanosoma cruzi. Methods: In this context, this study centres on the synthesis of a novel structural scaffold via molecular hybridisation; by using a triazole species to link a metronidazole unit to a eugenol analogue unit, the objective being to combine their therapeutic properties into a new molecular structure. The resulting hybrid molecules were evaluated against $T$. cruzi which is responsible for high incidences of trypanosomiasis in tropical countries such as Brazil. Results: The results of this study showed an improvement in the anti-parasitic activity of the hybrid compounds with the best result coming from hybrid compounds [8] and [9], which present an activity similar to the control drug benznidazole. The new compounds, utilising a triazole species as a coupling connector, demonstrated promising results and has highlighted the path for planning similar structural patterns to investigate new compounds. Conclusions: In summary, we can conclude that the synthesised hybrid compounds demonstrate that using a triazole to link metronidazole with natural phenols, produces hybrid molecules that are promising as a new class of compounds of therapeutic interest for further investigation.
\end{abstract}

\section{INTRODUCTION}

In medicinal chemistry, molecular hybridisation is a process which combines two or more pharmacophoric subunits to form a new compound called "a hybrid" which maintains the characteristics of the original compound $(1,2)$. It is expected that the new hybrid molecule may show improvements to its pharmacological action, reduced side effects and less toxicity when compared to the original components. The main effects expected through this strategy may be due to synergistic or additive effects (when they have the same pharmacological activity) but which act on different biochemical targets, or "doubleacting" when they present different biological activities on pathophysiology. Sometimes the new hybrid molecule has the effect where one of the subunits performs the therapeutic action and the other subunit will minimise or cancel the unwanted side effect caused by the first; in this case, we refer to the hybrid as a modulator (1-3).

In this context, this study focuses on the synthesis of a novel structural scaffold via molecular hybridisation; by linking a metronidazole unit to a eugenol analogue unit with the objective being to combine their therapeutic properties in a new molecular structure. Metronidazole itself was the first 5-nitroimidazole drug to be introduced into human therapy for the treatment of trichomoniasis and later for treating infections caused by a variety of anaerobic and microaerophilic bacteria such as Giardia lamblia, Trichomonas vaginalis, Entamoeba histolytica and Blastocystis sp protozoa $(4,5)$. Metronidazole is considered to be a prodrug, with the main mechanism of action involved with an intracellular bioreduction of the nitro group to a short-lived nitro anion radical, which is favourable in anaerobic or microaerophilic environments $(6,7)$. Eugenol (4allyl-2-methoxyphenol) is a natural phenol which 
is present in the essential oils of plants such as cloves, walnuts, nutmeg, and cinnamon and has historically important pharmacological properties such as: antibacterial, antifungal, antiparasitic, cytotoxic and antioxidant $(8,9)$.

Both metronidazole and substances of the eugenol family (with the same structural core) have therapeutic properties that can be applied in studies against trypanosomiasis, which are diseases caused by the parasitic protozoa of the genus Trypanosoma. An example of which is Trypanosoma cruzi (responsible for causing Chagas disease), a unicellular protozoan and obligate parasite that presents alternating cellular forms during its biological cycle; with the main ones being trypomastigote, epimastigote and amastigote (10). Benznidazole is the only drug approved in Brazil for the treatment of Chagas disease, however the existence of many strains that are resistant (either partially or fully) to this drug explains the therapeutic failures observed in the acute phase. For treatments carried out in the chronic phase (even in patients who are infected with a sensitive strain) it is observed that in most cases there is no cure - reinforcing the importance of researching new drugs to treat this disease (11).

A new structural nucleus containing a 5nitroimidazole unit, and a eugenol unit (or analogue) allows the projection of possible interactions with the various stages of the biological cycle of this parasite - which is of great interest and importance. There are several papers in the literature where researchers have synthesised metronidazole-triazole hybrids and tested their anti-amoebic properties $(12,13)$ and anti-bacterial properties (14-16) with varying results, and there is also a patent application focussed on some specific metronidazole-triazole hybrid molecules for their antibacterial properties and therapeutic usage (17).

Herein we report the synthesis of novel hybrids containing a metronidazole unit coupled to a eugenol analogue unit as shown in Figure 1. We chose to use a triazole linker, in order to explore the field known as click chemistry, which gained prominence in medicinal chemistry through the founding work conducted by K. Barry Sharpless (18). The well-known CuAAC reaction (copper (I) catalysed azide alkyne cycloaddition) directly links pharmacophoric molecules by means of a rigid 1,2,3-triazole 1,4-disubstituted unit $(18,19)$. This is an effective, quick and efficient method to produce bioactive molecules and this strategy is widely used in medicinal chemistry, as a method to efficiently connect units of therapeutic interest (2022). In order to obtain the desired hybrid molecules for this study, the functionalisation of metronidazole was performed which resulted in obtaining the key-intermediate azido species. In parallel, the preparation of the terminal propargyl of eugenol analogue phenols was carried out. These two units were subsequently coupled to form the new hybrid molecule, as shown in Figure 1, and described fully in the results section.

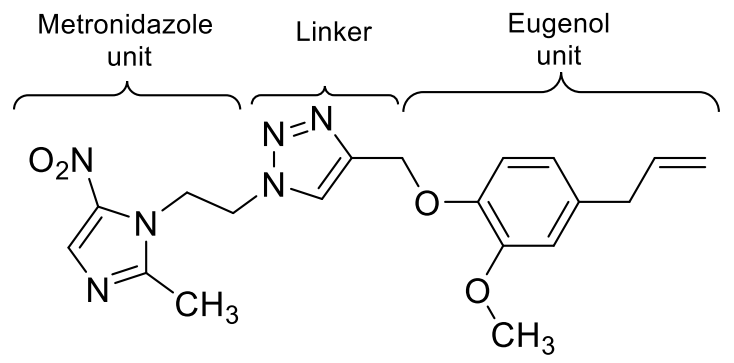

Figure 1. Molecular Structure of a MetronidazoleEugenol Hybrid

This hybrid structure is expected to be a new prototype for studies against infectious agents such as anaerobic or microaerophilic microorganisms, parasites, and protozoa, many of which cause diseases which are considered to be "Neglected Tropical Diseases" (NTD's) - communicable diseases that prevail in tropical and subtropical conditions in 149 countries affecting more than one billion people (23).

\section{METHODS AND MATERIALS}

All reagents and solvents were purchased from Sigma Aldrich and the $T$. cruzi strains were cultured and maintained in the Laboratory of Clinical \& Experimental Pathology and Parasitology (Laboratório de Patologia e Parasitologia Clínica e experimental) at UNIFALMG.

\section{Analytical Techniques \\ Fourier Transform InfraRed Spectroscopy.}

Fourier Transform InfraRed Spectroscopy (FTIR) was performed on a Shimadzu ${ }^{\circledR}$ Affinity-1 spectrometer using a zinc selenide attenuated total reflectance (ATR) sampling accessory supplied by Pike Technologies ${ }^{\circledR}$ (USA). Readings were taken at room temperature, 32 scans per analysis, resolution of $4.0 \mathrm{~cm}^{-1}$, range from $4000-600 \mathrm{~cm}^{-1}$.

\section{Nuclear Magnetic Resonance Spectroscopy.}

Nuclear Magnetic Resonance Spectroscopy (NMR) was performed on a Bruker ${ }^{\circledR} 300$ spectrometer. The ${ }^{1} \mathrm{H}$ and HSQC / HMQC experiments were recorded at $300 \mathrm{MHz}$ and ${ }^{13} \mathrm{C}$ experiments were recorded at $75 \mathrm{MHz}$. All samples were dissolved into $\mathrm{CDCl}_{3}$ as a solvent apart from compounds [1], [2] and [6] which, due 
to their low solubility in $\mathrm{CDCl}_{3}$ required the use of DMSO- $d_{6}$. Chemical shifts were recorded in parts per million $(\mathrm{ppm})$ based on the corresponding solvent. The abbreviations used for spin multiplicity were: $\mathrm{s}=$ singlet, $\mathrm{d}=$ doublet, $\mathrm{t}=$ triplet, $\mathrm{m}=$ multiplet.

\section{Liquid Chromatography-Mass Spectrometry.}

Liquid Chromatography-Mass Spectrometry (LCMS) analysis was performed on a Waters Acquity UPLC H-Class system; comprising a quaternary solvent manager attached to a triple-quadrupole (Acquity TQD) mass spectrometer. The samples were prepared in acetonitrile, and the mobile phase was acetonitrile spiked with $0.1 \%$ formic acid. The flow rate and injection volume were 0.4 $\mathrm{mL} / \mathrm{min}$ and $10.0 \mu \mathrm{L}$, respectively. Electrospray ionisation (ESI) with positive ionisation mode was found to be suitable and optimised as follows: cone voltage between 3 and $40 \mathrm{~V}$, capillary at $3 \mathrm{KV}$ and extractor $3 \mathrm{~V}$, source block temperature 120 ${ }^{\circ} \mathrm{C}$, desolvation line $500{ }^{\circ} \mathrm{C}$, nitrogen was used as the nebulising gas at 1000 litres/hour. The output signals were monitored and processed using Empower 3 software.

\section{Antiparasitic Assay Cultivation of Organisms}

The epimastigote forms of strain Y were obtained by culture in liver infusion tryptose (LIT) supplemented with $10 \%$ foetal bovine serum (FBS). The parasites were stored in $15 \mathrm{~mL}$ Falcon tubes and kept in a Bio-Oxygen Demand (BOD) incubator at $28{ }^{\circ} \mathrm{C}$; where every two days LIT medium was added to each Falcon tube containing the culture parasites, which due to the weekly breeding cycle, resulted in an exponential growth. For the anti-trypomastigote assay, tissue culturederived trypomastigotes were obtained from the first burst of H9c2 cells previously infected with blood trypomastigotes of the T. cruzi Y strain. The parasites were collected from the monolayer supernatant, purified as previously reported (24), and further resuspended in fresh culture medium. Parasites $\left(1 \times 10^{6}\right)$ were incubated for $24 \mathrm{~h}$ in $96-$ well plates, with different concentrations of the substances in 1:2 serial dilutions (200 at 1.56 $\mu \mathrm{g} / \mathrm{mL}$ ). The rates of parasite death were quantified by light microscopy to determine the $\mathrm{EC}_{50}(25)$.

\section{Construction of the Epimastigote Standard Curve.}

The construction of the epimastigote standard curve was performed according to the protocol described by Gonçalves-Santos et al. (26) with some modifications. After counting the epimastigotes in a Neubauer chamber, the concentration was adjusted to $1.5 \times 10^{6}$ parasites per ml. Seven serial dilutions (1:2) were made and subsequently pipetted into duplicate $(200 \mu \mathrm{l}$ per well) into 96-well plates. The plates were incubated in a BOD incubator at $28{ }^{\circ} \mathrm{C}$ for 72 hours. Soon after, $20 \mu \mathrm{l}$ of resazurin $(1 \mathrm{mM}$ previously standardised concentration) was added. In order to find the time interval where reading different concentrations was linear, the reaction was read at hourly intervals until the dye had totally reduced. Absorbance readings were taken at $570 \mathrm{~nm}$ for detecting the reduced form of the dye, and at 600 $\mathrm{nm}$ for detecting the oxidised form, in a Biochrom Anthos Zenyth 200rt microplate reader. The formula used was as follows: Resazurin reduction $=\left[\mathrm{A}_{570}-\left(\mathrm{A}_{600} \mathrm{X} \mathrm{R}_{0}\right)\right]$. Where $\mathrm{A}_{570}$ and $\mathrm{A}_{600}$ are absorbance readings at $570 \mathrm{~nm}$ and $600 \mathrm{~nm}$ respectively, $\mathrm{R}_{0}=$ factor of correction. The $\mathrm{R}_{0}$ factor was calculated from the absorbance values of the negative control (C), which contained LIT and resazurin in the absence of cells $\left[\mathrm{R}_{0}=\left(\mathrm{A}_{570} /\right.\right.$ $\left.\mathrm{A}_{600} \mathrm{C}\right)$ ]. To construct the standard curve, the number of parasites was plotted versus the percentage of dye reduction. Therefore, calculating the ideal amount of epimastigotes and the optimal incubation time in order to obtain a linear reaction.

\section{Evaluation of Anti - T. cruzi Activity}

In order to assess the trypanocidal potential of natural substances using Benznidazole as the reference drug; for each substance tested, 8 decreasing concentrations (1:2 dilution) were used in triplicate, with the initial concentration being $150 \mu \mathrm{g} / \mathrm{ml}$. A volume of $150 \mu \mathrm{l}$ per well was added for each dilution into a sterile 96 well plate. After cultivation and maintenance of epimastigote forms (as previously described), the number of parasites were counted in a Neubauer chamber so that the concentration was $1.5 \times 10^{6} / \mathrm{ml}$ which was then added to the wells containing the dilution series of all compounds. Each plate also contained the following controls: negative control (containing only the LIT culture medium), positive control (containing the LIT and the parasite) and controls containing the culture medium and the drug in the absence of the parasite to evaluate the potential of the drug to reduce the dye.

The plates were incubated for 72 hours in a BOD incubator at $28^{\circ} \mathrm{C}$ and then resazurin $(20 \mu \mathrm{L})$ was added to all wells and the plate was incubated for an additional 12 hours at $28{ }^{\circ} \mathrm{C}$. After the incubation period, using the Biochrom Anthos Zenyth 200rt microplates, readings were taken at $570 \mathrm{~nm}$ and $600 \mathrm{~nm}$ and the formula used to calculate the inhibition was: \% inhibition $=[100-$ $\mathrm{A}_{570}-\left(\mathrm{A}_{600} * \mathrm{R}_{0}\right)$ Treated / $\mathrm{A}_{570}-\left(\mathrm{A}_{600} * \mathrm{R}_{0}\right)$ Control+] $* 100$ 
Where $\mathrm{A}_{570} \& \mathrm{~A}_{600}=$ absorbance at $570 \mathrm{~nm}$ \& $600 \mathrm{~nm}$ respectively, $\mathrm{R}_{0}=$ correction factor. The $\mathrm{R}_{0}$ correction factor was calculated from the absorbance values of the negative control (culture medium + resazurin in the absence of parasites) using the formula $\left[\mathrm{R}_{0}=\left(\mathrm{A}_{570} / \mathrm{A}_{600}\right)\right]$. After calculating the percentage of inhibition of each drug concentration and the tested substances, the computer program "Graph Pad Prism 5" was used in order to calculate the inhibitory concentration $\left(\mathrm{IC}_{50}\right)$ of the drug. The $\mathrm{IC}_{50}$ being the concentration at which $50 \%$ of the organism population is inhibited.

\section{Additional Properties}

The physicochemical and pharmacokinetic properties, toxicity and druglikeness of the synthesised compounds were predicted using the OSIRIS Property Explorer (27) and SwissADME databases (28). The Bioactivity score of these compounds were predicted using the online "Molinspiration" property calculator (29).

\section{RESULTS}

\section{Molecular Synthesis - Overview}

The first step of this work involved the preparation of the key intermediate azido species of metronidazole [2] by classical organic synthesis (Scheme 1, Part 1), and the preparation of the propargyl derivatives from eugenol analogue phenols (Scheme 1, Part 2) to form compounds [3], [4] and [5].

As indicated in Scheme 2, the reaction was carried out in $t$-butanol, at room temperature, using copper sulfate as a catalyst which is an efficient method that provided all products with yields ranging from 80 to $92 \%$ yield. The compounds shown in Schemes 1 \& 2 were synthesised using the following procedures. In addition to the analytical data shown below, a supplementary file containing all the analytical data is also available online.

Synthesis of Compound [2] Step a: In a round bottom flask containing metronidazole (5.34 $\mathrm{mmol}$ ) and anhydrous pyridine (5 $\mathrm{ml})$, methanesulfonyl chloride $(21.36 \mathrm{mmol})$ was added whilst kept in an ice bath, and the mixture was kept at $-4{ }^{\circ} \mathrm{C}$ for 24 hours. The crude product was treated with $\mathrm{HCl} 12 \mathrm{M}$, dropwise, at $0{ }^{\circ} \mathrm{C}$ (ice bath), until reaching $\mathrm{pH}=0$ as measured using $\mathrm{pH}$ indicator strips (Merck colorpHast ${ }^{\circledR}$ ). The white precipitate that was formed, was filtered under vacuum resulting in a pure white solid which is the intermediary compound [1].
Step b: In a round bottomed flask containing dimethylformamide (3 ml), compound [1] (4.02 mmol) and sodium azide ( $24.12 \mathrm{mmol}$ ) was added. The mixture was kept under magnetic stirring and heating $\left(80{ }^{\circ} \mathrm{C}\right)$ overnight. The solvent was removed under reduced pressure, and the crude product was suspended in cold distilled water and then filtered under vacuum to produce $0.67 \mathrm{~g}$ of pure compound [2]. From a safety perspective, it is worth highlighting that sodium azide must be handled appropriately due to its hazardous properties. Sodium azide itself is highly toxic to both humans and the environment and can react to form potentially explosive compounds and may have incompatibilities with some metals, strong acids, and certain chlorinated solvents. Before attempting to use the synthesis route described above, these authors recommend researching the safe usage guidelines for sodium azide before attempting to repeat the reactions described herein.

\section{Analytical Data:}

- Compound [1] IUPAC Name: 2-(2-methyl-5nitro-1H-imidazol-1-yl)ethyl

methanesulfonate. Appearance: White solid. Yield: $95 \%$. m.p.: $165.2-167.1^{\circ} \mathrm{C}$; IR (ATR, $\left.\mathrm{cm}^{-1}\right): 3058(\mathrm{C} 4-\mathrm{H}), 2805(\mathrm{C} 6,7,8-\mathrm{H}), 1351$ $(\mathrm{S}=\mathrm{O}), 1118(\mathrm{~S}=\mathrm{O}), 1285(\mathrm{~N}=\mathrm{O}), 1108(\mathrm{~N}=\mathrm{O})$, 1055 (C-O). ${ }^{1} \mathrm{H}$ NMR [300 MHz, DMSO- $d_{6}$, (ppm)]: 8.07 [s, 1H, H4], $4.65\left[\mathrm{t},{ }^{3} J=6.3 \mathrm{~Hz}\right.$, $2 \mathrm{H}, \mathrm{H} 8], 4.55\left[\mathrm{t},{ }^{3} \mathrm{~J}=6.3 \mathrm{~Hz}, 2 \mathrm{H}, \mathrm{H} 7\right], 3.15[\mathrm{~s}$, $\left.3 \mathrm{H},-\mathrm{SO}_{2} \mathrm{CH}_{3}\right], 2.46[\mathrm{~s}, 3 \mathrm{H}, \mathrm{H} 6] .{ }^{13} \mathrm{C}$ NMR $[100$ MHz, DMSO- $\left.d_{6}(\mathrm{ppm})\right]: 152.18$ [C1], 138.89 [C5], 133.51 [C4], 68.95 [C8], 45.54 [C7], $37.14\left[-\mathrm{SO}_{2} \mathrm{CH}_{3}\right], 13.46$ [C6].

- Compound [2] IUPAC Name: 1-(2azidoethyl)-2-methyl-5-nitro-1H-imidazole. Appearance: White solid. Yield: $85 \%$; m.p.: $171.8-172.5^{\circ} \mathrm{C}$; IR (ATR, $\left.\mathrm{cm}^{-1}\right)$ : $3055(\mathrm{C} 4-$ $\mathrm{H}), 2811(\mathrm{C} 6,7,8-\mathrm{H}), 2108(\mathrm{~N}=\mathrm{N}=\mathrm{N}), 1285$ $(\mathrm{N}=\mathrm{O}), 1108(\mathrm{~N}=\mathrm{O}), 1051(\mathrm{C}-\mathrm{O}) .{ }^{1} \mathrm{H}$ NMR [300 MHz, DMSO- $\left.d_{6},(\mathrm{ppm})\right]: 8.02[\mathrm{~s}, 1 \mathrm{H}$, $\mathrm{H} 4], 4.44\left[\mathrm{t},{ }^{3} \mathrm{~J}=6.3 \mathrm{~Hz}, 2 \mathrm{H}, \mathrm{H} 7\right], 3.73\left[\mathrm{t},{ }^{3} \mathrm{~J}=\right.$ $6.3 \mathrm{~Hz}, 2 \mathrm{H}, \mathrm{H} 8], 2.44$ [s, 3H, H6]. ${ }^{13} \mathrm{C}$ NMR [100 MHz, DMSO- $d_{6}(\mathrm{ppm})$ ]: 151.99 [C2], 138.79 [C5], 133.60 [C4], 50.47 [C8], 45.39 [C7], 14.43 [C6].

\section{Synthesis of the Propargyl Derivatives [3-5].}

In a round bottomed flask containing dimethylformamide $(5 \mathrm{ml})$, the corresponding phenol (1.83 mmol), sodium carbonate (5.49 mmol), propargyl bromide $(5.49 \mathrm{mmol})$ and $5 \%$ w/v of molecular sieve ( $4 \AA$ ) were added. The mixture reaction was kept under magnetic stirring 
and heating $\left(100^{\circ} \mathrm{C}\right)$ for 24 hours. The solvent was removed under reduced pressure, and the crude product obtained was dissolved in ethyl acetate (20 $\mathrm{ml})$ and washed 3 times with distilled water $(20$ $\mathrm{ml})$. Then the resulting organic phase was dried with sodium sulfate and the solvent was removed under reduced pressure. The average yield of the pure products obtained was $\sim 70 \%$.

\section{Part 1}

Step a: methanesulfonyl chloride, pyridine, $0^{\circ} \mathrm{C}, 24 \mathrm{~h}$

Step b: sodium nitrite, dimethylformamide, $80^{\circ} \mathrm{C}, 12 \mathrm{~h}$<smiles>Cc1ncc([N+](=O)[O-])n1CCO</smiles>

$\frac{\text { Step a }}{\text { Yield: } 95 \%}$<smiles>Cc1ncc([N+](=O)[O-])n1CCOS(C)(=O)=O</smiles>

[1]<smiles>Cc1ncc([N+](=O)[O-])n1CCN</smiles>

[2]

\section{Part $\underline{2}$}

Step c: propargyl bromide, potassium carbonate, dimethylformamide, $80^{\circ} \mathrm{C}, 24 \mathrm{~h}$<smiles>[R]c1ccc(O)c(OC)c1</smiles><smiles>CC=CCOc1ccc(P)cc1OC</smiles>

[3] [4] [5]

$$
\begin{aligned}
& \text { [3] } \mathrm{R}=\mathrm{H} \\
& \text { [4] } \mathrm{R}=
\end{aligned}
$$$$
\text { [5] } \mathrm{R}=\mathrm{s}
$$

Scheme 1 General Reaction Scheme for the Preparation of the Hybrid Molecules. Intermediary azido species of metronidazole [2] was obtained with an $81 \%$ overall yield, and the natural phenols (eugenol, dihydroeugenol and guaiacol) were converted into their respective propargyl derivatives (compounds [3], [4] and [5]) by reaction with propargyl bromide and potassium carbonate with satisfactory yields $(\sim 70 \%)$. In the second step to synthesise the "hybrid" compounds, we utilised a 1,2,3-triazole,1,4-disubstituted unit as a linker via a CuAAC reaction, to couple compound [2] with compounds [3], [4] and [5] to form compounds [7], [8] and [9] respectively as shown in Scheme 2 (18-22). Compound [6] which was synthesised by coupling propargyl alcohol with compound [2], was selected in order to allow us to better understand the importance of phenolic units linked to the nitroimidazole nucleus.

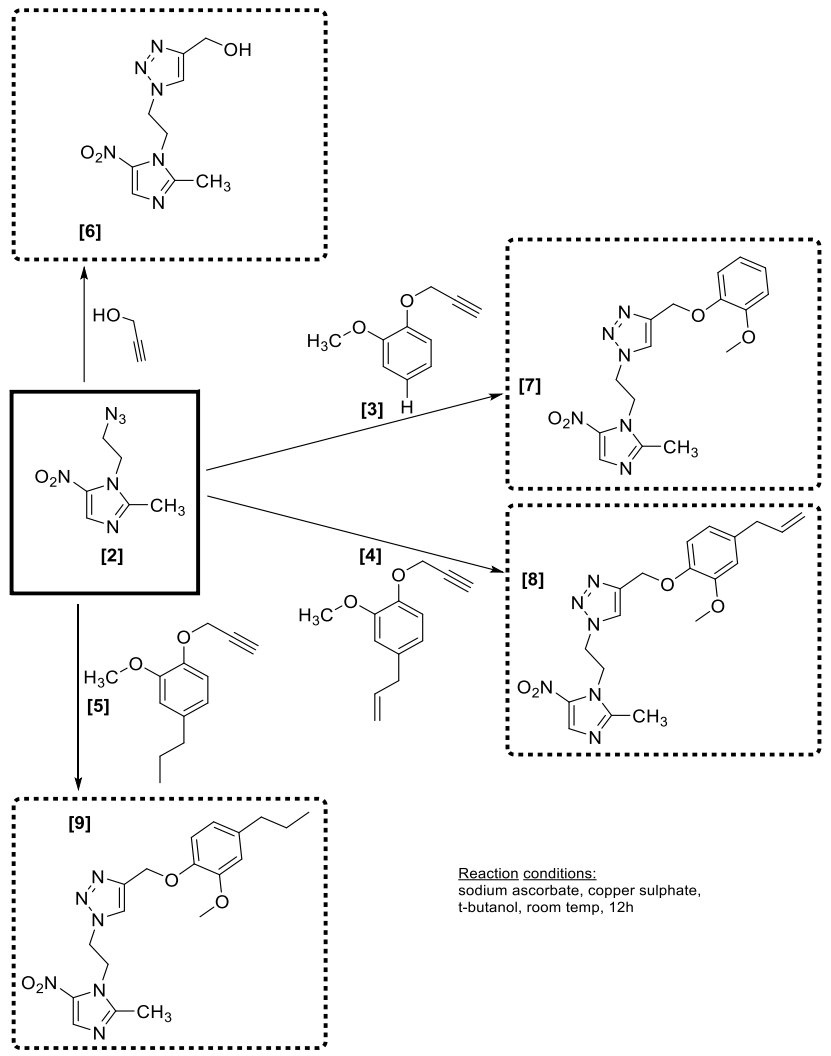

Scheme 2. Coupling Reaction Scheme to Form Compounds [6] to [9]. 


\section{Analytical Data:}

- Compound [3] IUPAC Name: 4-allyl-2methoxy-1-(prop-2-yn-1-yloxy)benzene.

Appearance: Brown oil. Yield: 72\%; IR (ATR, $\left.\mathrm{cm}^{-1}\right): 3311(\mathrm{C} 10-\mathrm{H}), 3010(\mathrm{CAr}-\mathrm{H}), 2105$ $(\mathrm{C} \equiv \mathrm{C}), 1504(\mathrm{C}=\mathrm{C}), 1035(\mathrm{C}-\mathrm{O}) .{ }^{1} \mathrm{H}$ NMR [300 MHz, $\left.\mathrm{CDCl}_{3},(\mathrm{ppm})\right]: 6.95$ [m, 4H, H3'6'], 4.77 [s, 2H, H8'], 3.87 [s, 3H, H7'], 2.51 $[\mathrm{s}, 1 \mathrm{H}, \mathrm{H} 10] .{ }^{13} \mathrm{C}$ NMR $\left[100 \mathrm{MHz}, \mathrm{CDCl}_{3}\right.$ (ppm)]: 149.7 [C1'], 146.7 [C2'], 122.3 [C4'], 120.7 [C5'], 114.4 [C6'], 111.8 [C3'], 78.5 [C9], 75.7 [C10], 56.6 [C8'], 55.8 [C7'].

- Compound [4] IUPAC Name: 2-methoxy-1(prop-2-yn-1-yloxy)-4-propylbenzene.

Appearance: Brown oil. Yield: 68\%; IR (ATR, $\left.\mathrm{cm}^{-1}\right)$ : $3308(\mathrm{C} 10-\mathrm{H}), 3005(\mathrm{CAr}-\mathrm{H}), 2111$ $(\mathrm{C} \equiv \mathrm{C}), 1511 \quad(\mathrm{C}=\mathrm{C}), 1045 \quad(\mathrm{C}-\mathrm{O}) .{ }^{1} \mathrm{H}$ NMR [300 MHz, $\left.\mathrm{CDCl}_{3},(\mathrm{ppm})\right]: 6.93\left[\mathrm{~d},{ }^{3} J=8.1 \mathrm{~Hz}\right.$, 1H, H6'], 6.72 [m, 2H, H3', H5'], 4.72 [s, 2H, H8'], 4.11 [s, 1H, H10], 3.65 [s, 3H, H7'], 2.51 $\left[\mathrm{t},{ }^{3} J=7.6 \mathrm{~Hz}, 2 \mathrm{H}, \mathrm{Ar}-\mathrm{CH}_{2}\right], 1.61\left[\mathrm{~s},{ }^{3} J=7.6\right.$ $\left.\mathrm{Hz}, 2 \mathrm{H},-\mathrm{CH}_{2}\right], 0.93$ [t, $\left.{ }^{3} \mathrm{~J}=7,6 \mathrm{~Hz}, 3 \mathrm{H},-\mathrm{CH}_{3}\right]$. ${ }^{13} \mathrm{C}$ NMR [100 $\mathrm{MHz}, \mathrm{CDCl}_{3}$ (ppm)]: 149.9 [C2'], 149.4 [C1'], 136.9 [C4'], 120.1 [C5'], 114.5 [C6'], 112.2 [C3'], 78.9 [C9], 75.5 [C10], 56.9 [C8'], 55.8 [C7'], 37.7 [ $\mathrm{Ar}-\mathrm{C}_{2}{ }_{2}$, $29.7\left[\mathrm{CH}_{2}{ }^{\prime}\right], 14,2\left[\underline{\mathrm{CH}}_{3}\right]$.

- Compound [5] IUPAC Name: 1-methoxy-2(prop-2-yn-1-yloxy)benzene.

Appearance: Brown oil. Yield: 71\%; IR (ATR, $\left.\mathrm{cm}^{-1}\right)$ : $3299(\mathrm{C} 10-\mathrm{H}), 3007$ (CAr-H), 2115 $(\mathrm{C} \equiv \mathrm{C}), 1499(\mathrm{C}=\mathrm{C}), 1045(\mathrm{C}-\mathrm{O}) .{ }^{1} \mathrm{H}$ NMR $\left[300 \mathrm{MHz}, \mathrm{CDCl}_{3},(\mathrm{ppm})\right]: 6.97\left[\mathrm{~d},{ }^{3} J=8.6 \mathrm{~Hz}\right.$, 1H, H6'], 6.74 [m, 2H, H3', H5'], 5.96 [m, 1H, $\left.\mathrm{C} \underline{H}=\mathrm{CH}_{2}\right], 5.08\left[\mathrm{~m}, 2 \mathrm{H}, \mathrm{CH}=\mathrm{C}_{2}\right], 4.74\left[\mathrm{~d},{ }^{3} \mathrm{~J}\right.$ $\left.=2.4 \mathrm{~Hz}, 2 \mathrm{H}, \mathrm{H} 8^{\prime}\right], 3.86\left[\mathrm{~s}, 3 \mathrm{H}, \mathrm{H} 7^{\prime}\right], 3.34[\mathrm{~d}$, $\left.{ }^{3} \mathrm{~J}=6.8 \mathrm{~Hz}, 2 \mathrm{H}, \mathrm{Ar}-\mathrm{CH}_{2}{ }^{\prime}\right], 2.49\left[\mathrm{t},{ }^{3} \mathrm{~J}=2.4 \mathrm{~Hz}\right.$, $2 \mathrm{H}, \mathrm{H10}] .{ }^{13} \mathrm{C} \mathrm{NMR}$ [100 MHz, $\left.\mathrm{CDCl}_{3}(\mathrm{ppm})\right]$ : 149.6 [C2'], 145.1 [C1'], $137.5\left[\underline{\mathrm{CH}}=\mathrm{CH}_{2}\right]$, $133.2 \quad\left[\mathrm{C}^{\prime}\right.$ '], $120.3 \quad$ [C5'], 115.8 $\left[\mathrm{CH}=\mathrm{CH}_{2}\right], 114.5 \quad\left[\mathrm{C}^{\prime}\right.$ '], $112.3 \quad$ [C3'], 78.8 [C9], 75.7 [C10], 56.9 [C8'], 55.8 [C7'], 39.9 [Ar- $\left.\underline{\mathrm{C}} \mathrm{H}_{2}\right]$.

\section{Synthesis of Hybrid Compounds [6-9].}

In a round bottomed flask containing of tertbutanol ( $3 \mathrm{ml})$, the appropriate propargyl derivative (1 mmol) was added, followed by of sodium ascorbate $(0.8 \mathrm{mmol})$, copper sulfate $(0.08 \mathrm{mmol})$ and $1 \mathrm{mmol}$ of compound [1]. The reaction mixture was kept under magnetic stirring at room temperature for 24 hours. The solvent was removed under reduced pressure and the obtained crude product was dissolved in chloroform $(20 \mathrm{ml})$ and washed three times with a $2 \%$ ethylenediaminetetraacetic acid aqueous solution. The resulting organic phase was dried over sodium sulfate, and the solvent was removed under reduced pressure. The average yield of the pure compounds by this method ranged between $80 \%$ to $92 \%$ yield. Analytical Data:

- Compound [6] IUPAC Name: (1-(2-(2-methyl5-nitro-1H-imidazol-1-yl)ethyl)-1H-1,2,3triazol-4-yl)methanol.

Appearance: Pale yellow solid. Yield: 92\%; m.p.: $147.5-149.1^{\circ} \mathrm{C}$; IR (ATR, $\left.\mathrm{cm}^{-1}\right)$ : 3059 (C10-H), 3015 (CAr-H), $1504(\mathrm{C}=\mathrm{C}), 1284$ $(\mathrm{N}=\mathrm{O}), 1118(\mathrm{~N}=\mathrm{O}), 1051 \quad(\mathrm{C}-\mathrm{O})$. LC-MS (ESI) $\mathrm{m} / \mathrm{z}$ calculated for $\mathrm{C}_{9} \mathrm{H}_{12} \mathrm{~N}_{6} \mathrm{O}_{3}=252.10$, $\mathrm{m} / \mathrm{z}+\mathrm{H}^{+}=253.0$, found 253.00. ${ }^{1} \mathrm{H}$ NMR [300 MHz, DMSO- $\left.d_{6},(\mathrm{ppm})\right]: 8.04[\mathrm{~s}, 1 \mathrm{H}, \mathrm{H} 4]$, $7.87\left[\mathrm{~s}, 1 \mathrm{H}, \mathrm{H} 10^{\prime}\right], 5.25\left[\mathrm{t},{ }^{3} \mathrm{~J}=5.7 \mathrm{~Hz}, 1 \mathrm{H}\right.$, $\mathrm{OH}], 4.79\left[\mathrm{t},{ }^{3} \mathrm{~J}=5.7 \mathrm{~Hz}, 2 \mathrm{H}, \mathrm{H} 8\right], 4.68\left[\mathrm{t},{ }^{3} \mathrm{~J}=\right.$ $5.7 \mathrm{~Hz}, 2 \mathrm{H}, \mathrm{H} 7], 4.47$ [d, $\left.{ }^{3} \mathrm{~J}=5.7 \mathrm{~Hz}, 2 \mathrm{H}, \mathrm{H} 11\right]$, 1.83 [s, 3H, H6]. $\mathrm{C}^{13} \mathrm{NMR}$ [100 MHz, DMSO$\left.d_{6},(\mathrm{ppm})\right]: 151.8[\mathrm{C} 2], 149.9$ [C9'], 138.9 [C5], 133.7 [C4], 124.1 [C10'], 53.3 [C8], 49.0 [C8'], 46.7 [C7], 13.3 [C6].

- Compound [7] IUPAC Name: 4-((2methoxyphenoxy)methyl)-1-(2-(2-methyl-5nitro-1H-imidazol-1-yl)ethyl)-1H-1,2,3triazole.

Appearance: Pale yellow solid. Yield: 82\%; m.p.: $117.1-117.9^{\circ} \mathrm{C}$; IR (ATR, $\left.\mathrm{cm}^{-1}\right): 3055$ (C10-H), 3011 (CAr-H), $1507 \quad(\mathrm{C}=\mathrm{C}), 1294$ $(\mathrm{N}=\mathrm{O}), 1201(\mathrm{~N}=\mathrm{O}), 1032(\mathrm{C}-\mathrm{O}) . \quad$ LC-MS (ESI) $\mathrm{m} / \mathrm{z}$ calculated for $\mathrm{C}_{16} \mathrm{H}_{18} \mathrm{~N}_{6} \mathrm{O}_{4}=358.14$, $\mathrm{m} / \mathrm{z}+\mathrm{H}^{+}=359.14$, found 359.08 . ${ }^{1} \mathrm{H} \mathrm{NMR}$ [300 MHz, $\left.\mathrm{CDCl}_{3},(\mathrm{ppm})\right]: 7.97$ [s, 1H, H4], 7.40 [s, 1H, H10'], 6.91 [m, 4H, H3'-H6'], 5.25 [s, 2H, H8'], 4.77 [s, 4H, H7, H8], 3.85 [s, $3 \mathrm{H}, \mathrm{H} 7$ '], 1.92 [s, 3H, H6]. ${ }^{13} \mathrm{C}$ NMR [100 $\left.\mathrm{MHz}, \mathrm{CDCl}_{3},(\mathrm{ppm})\right]: 151.3$ [C2], 149.6 [C9'], 147.2 [C1'], 145.3 [C2'], 138.1 [C5], 133.8 [C4], 123.8 [C10'], 122.1 [C5'], 120.1 [C6'], 114.1 [C4'], 111.9 [C3'], 62.7 [C8'], 55.9 [C7'], 49.6 [C8], 46.4 [C7], 13.3 [C6].

- Compound [8] IUPAC Name: 4-((4-allyl-2methoxyphenoxy)methyl)-1-(2-(2-methyl-5nitro-1H-imidazol-1-yl)ethyl)-1H-1,2,3triazole.

Appearance: Pale yellow solid. Yield: $80 \%$; m.p.: $113.1-114.5^{\circ} \mathrm{C}$; IR (ATR, $\mathrm{cm}^{-1}$ ): 3033 (C10-H), 3014 (CAr-H), $1518(\mathrm{C}=\mathrm{C}), 1255$ $(\mathrm{N}=\mathrm{O}), 1237(\mathrm{~N}=\mathrm{O}), 1035$ (C-O). LC-MS (ESI) $\mathrm{m} / \mathrm{z}$ calculated for $\mathrm{C}_{19} \mathrm{H}_{22} \mathrm{~N}_{6} \mathrm{O}_{4}=398.17$, $\mathrm{m} / \mathrm{z}+\mathrm{H}^{+}=399.17$, found 399.13. ${ }^{1} \mathrm{H} \mathrm{NMR}$ [300 MHz, $\mathrm{CDCl}_{3},(\mathrm{ppm})$ ]: 7.97 [s, 1H, H4], $7.40\left[\mathrm{~s}, 1 \mathrm{H}, \mathrm{H} 10^{3}\right], 6.87\left[\mathrm{~d},{ }^{3} \mathrm{~J}=7.8 \mathrm{~Hz}, 1 \mathrm{H}\right.$, H6'], 6.72 [m, H3', H5'], $5.92[\mathrm{~m}, 1 \mathrm{H}$, $\left.\mathrm{C} \underline{\mathrm{H}}=\mathrm{CH}_{2}\right], 5.22\left[\mathrm{~s}, 2 \mathrm{H}, \mathrm{H} 8^{\prime}\right], 5.07[\mathrm{~m}, 2 \mathrm{H}$, 
$\mathrm{C}=\mathrm{C}_{2}$ ], 4.76 [m, 4H, H7, H8], 3.85 [s, 3H, $\mathrm{H} 7^{\prime}$ ], $3.31\left[\mathrm{~d},{ }^{3} \mathrm{~J}=8.0 \mathrm{~Hz}, 2 \mathrm{H}, \mathrm{Ar}-\mathrm{C}_{2}{ }_{2}\right.$ ], 1.94, [s, 3H, H6]. ${ }^{13} \mathrm{C}$ NMR [100 $\mathrm{MHz}, \mathrm{CDCl}_{3}$, (ppm)]: 151.3 [C2], 149.5 [C9'], 145.5 [C2'], 145.41 [C1'], 137.5 [C5], 134.4 [C4'], 133.8 [C4], $133.5\left[\mathrm{C} \underline{\mathrm{CH}}=\mathrm{CH}_{2}\right], 123.8$ [C10'], 120.5 [C5'], $\left.115.8\left[\mathrm{CH}^{-} \underline{\mathrm{CH}}_{2}\right]\right], 114.5$ [C6'], 112.4 [C3'], 62.9 [C8'], 55.8 [C7'], 49.6 [C8], 46.4 [C7], 39.8 [ $\left.\mathrm{Ar}-\mathrm{CH}_{2}\right], 13.4$ [C6].

- Compound [9] IUPAC Name: 4-((2-methoxy4-propylphenoxy)methyl)-1-(2-(2-methyl-5nitro-1H-imidazol-1-yl)ethyl)-1H-1,2,3triazole.

Appearance: Pale yellow solid. Yield: 88\%; m.p.: $118.8-120.3^{\circ} \mathrm{C}$; IR (ATR, $\left.\mathrm{cm}^{-1}\right)$ : 3049 $(\mathrm{C} 10-\mathrm{H}), 3010(\mathrm{CAr}-\mathrm{H}), 1508(\mathrm{C}=\mathrm{C}), 1285$ $(\mathrm{N}=\mathrm{O}), 1215(\mathrm{~N}=\mathrm{O}), 1033$ (C-O). LC-MS (ESI) $\mathrm{m} / \mathrm{z}$ calculated for $\mathrm{C}_{19} \mathrm{H}_{24} \mathrm{~N}_{6} \mathrm{O}_{4}=400.19$, $\mathrm{m} / \mathrm{z}+\mathrm{H}^{+}=401.19$, found 401.16. ${ }^{1} \mathrm{H}$ NMR [300 MHz, $\mathrm{CDCl}_{3},(\mathrm{ppm})$ ]: 7.97 [s, 1H, H4], 7.39 [s, 1H, H10'], $6.84\left[\mathrm{~d},{ }^{3} J=8.1 \mathrm{~Hz}, 1 \mathrm{H}\right.$, H6'], 6.67 [m, H3', H5'], 5.21 [s, 2H, H8'], 4.75 [s, 4H, H7, H8], 3.81 [s, 3H, H7'], 2.50 [t, $\left.{ }^{3} J=7.9 \mathrm{~Hz}, 2 \mathrm{H}, \mathrm{Ar}-\mathrm{C}_{2}\right], 1.95,[\mathrm{~s}, 3 \mathrm{H}, \mathrm{H} 6]$, $1.60\left[\mathrm{~s},{ }^{3} J=7,3 \mathrm{~Hz}, 2 \mathrm{H},-\mathrm{CH}_{2}\right], 0.94\left[\mathrm{t},{ }^{3} J=7.3\right.$ $\left.\mathrm{Hz}, 3 \mathrm{H},-\mathrm{C}_{3}\right] .{ }^{13} \mathrm{C} \mathrm{NMR}\left[100 \mathrm{MHz}, \mathrm{CDCl}_{3}\right.$, (ppm)]: 149.3 [C2], 145.5 [C9'], 145.2 [C2'], 136.8 [C1'], 133.9 [C5], 133.6 [C4'], 133.5 [C4], 123.8 [C10'], 120.3 [C5'], 114.3 [C6'], 112.3 [C3'], 62.9 [C8'], 55.8 [C7'], 49.6 [C8], $46.4[\mathrm{C} 7], 37.7\left[\mathrm{Ar}-\underline{\mathrm{CH}}_{2}\right], 24.7\left[\mathrm{CH}_{2}\right], 13.8$ $\left[\mathrm{CH}_{3}\right], 13.4[\mathrm{C} 6]$.

To further confirm the successful formation of the desired hybrid compounds, FTIR (ATR), LCMS (ESI) and NMR spectrometry were used; Figure 2 shows the ${ }^{1} \mathrm{H}$ NMR spectra of the keyintermediate azido compound [2], the propargylguaiacol [3] and the hybrid molecule obtained from this coupling [7] to demonstrate the success of the reaction pathway. The key point from this ${ }^{1} \mathrm{H}$ NMR analysis is the presence of the signal at $7.45 \mathrm{ppm}$ which is characteristic of the triazole hydrogen (H10), and its presence corroborates the formation of the hybrid structure. The remaining signals are marked in the spectrum.

Figure 3 shows the $2 \mathrm{D}{ }^{1} \mathrm{H}$ NMR spectrums of compound [7] using the well-known HSQC and HMBC experiments which, when the data is combined, enables the confirmation that the substituent unit is present on carbon 9'. The HSQC (Heteronuclear Single Quantum Coherence) experiment is used to confirm the presence of proton-carbon single bonds, whereas the HMBC (Heteronuclear Multiple Bond Correlation) experiment confirms the presence of proton-carbon bonds separated by $2-4$ bonds, such as those in conjugated systems (30).

In the HSQC experiment, the one bond interaction of $\mathrm{H}^{1}{ }^{\prime} \times \mathrm{C} 10^{\prime}$ allows confirmation that the C10' (at $123.9 \mathrm{ppm}$ ), is the only hydrogenated carbon of the triazole ring. The HMBC spectrum gives the long distance (three bonds) interactions, and the observed correlation of C10' $x$ H8 allows the verification, as expected, of the triazole obtained.

From the FTIR (ATR), LCMS (ESI), ${ }^{1} \mathrm{H}$ NMR and ${ }^{13} \mathrm{C}$ NMR spectrometry data obtained, the structures of compounds [6] to [9] were therefore concluded to be as expected and previously shown in Scheme 2. These compounds were then assessed in a number of ways as explained in the following sections.

\section{Antiparasitic Assay}

We evaluated the bioactive potential of the hybrid compounds (compared to the original pharmacophores of metronidazole \& eugenol) against the epimastigote form of $T$. cruzi as shown in Figure 4 and discussed in the next section. This assay is the most common in biological studies of this protozoa, but the epimastigote form is present in the vector. Although it is possible to make a comparison of these results against this form, the answer is even more compatible when evaluated against trypomastigote forms of the protozoan. Therefore, the study was also carried out against trypomastigote forms, and the results are shown in Figure 5 and discussed in the next section.

\section{DISCUSSION}

As previously mentioned, from the FTIR (ATR), LCMS(ESI), ${ }^{1} \mathrm{H}$ NMR and ${ }^{13} \mathrm{C}$ NMR spectrometry data obtained, the structures of compounds [6] to [9] were concluded to be as expected and previously shown in Scheme 2.

\section{Evaluation of Anti - T. cruzi Activity Testing the hybrids molecules against the Epimastigote form of T. cruzi.}

From the results shown in Figure 4, it is possible to conclude that metronidazole and eugenol have a moderate anti-trypanosomal action against the epimastigote form of $T$. cruzi, with $\mathrm{IC}_{50}$ values of $191 \mu \mathrm{M} \pm 8 \mu \mathrm{M}$ and $161 \mu \mathrm{M} \pm 7 \mu \mathrm{M}$ respectively. For reference, Santoro et al. (31) published an $\mathrm{IC}_{50}$ value for eugenol of $246 \mu \mathrm{g} / \mathrm{ml}$ (no error reported) which is roughly comparable to our findings. The triazole compound [6], can be considered to not possess any activity with an $\mathrm{IC}_{50}$ value of $602 \mu \mathrm{M}$ $\pm 23 \mu \mathrm{M}$. The hybrid molecules[7-9] showed an 


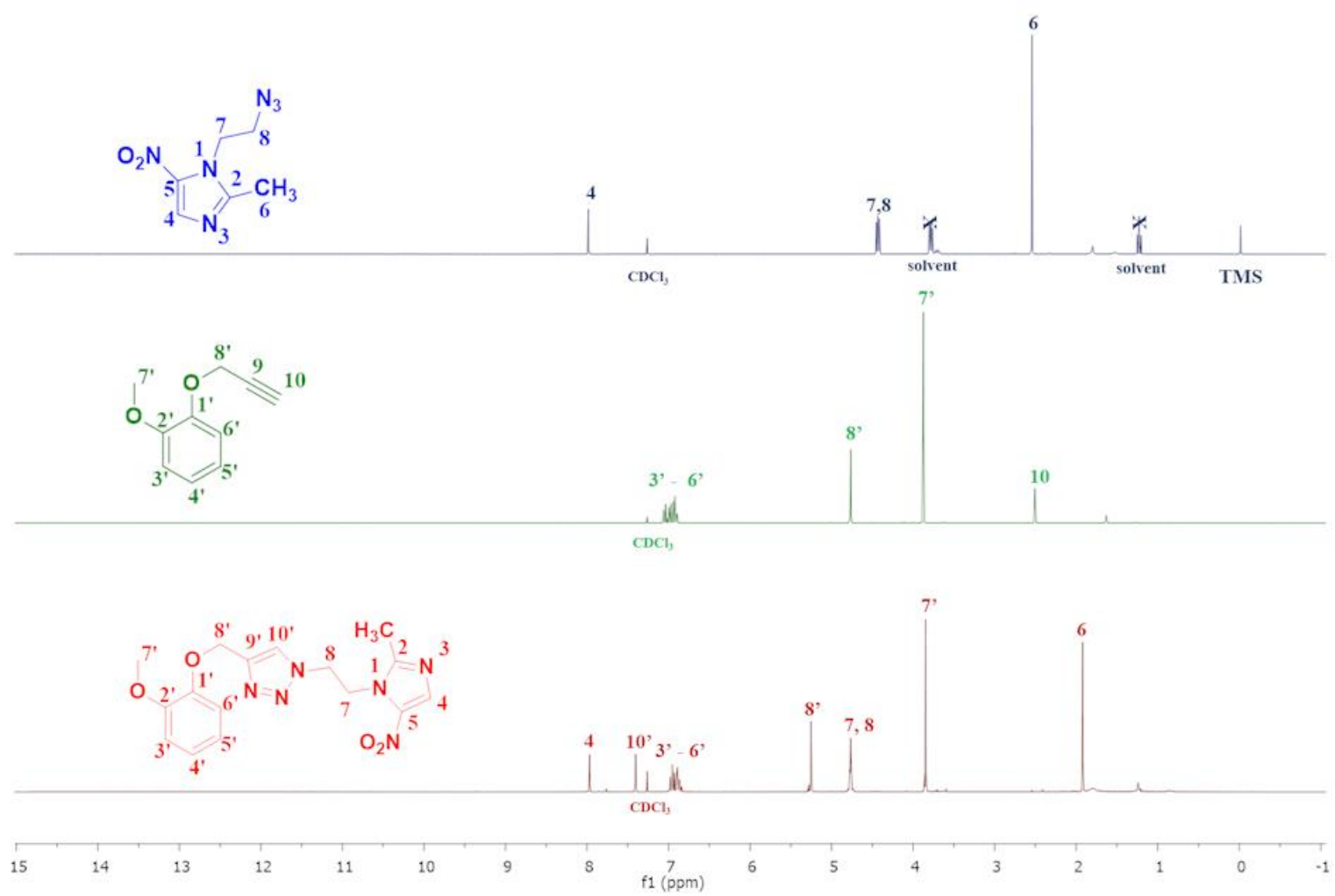

Figure 2. Comparative ${ }^{1} \mathrm{H}$ NMR Spectra $\left(300 \mathrm{MHz}, \mathrm{CDCl}_{3}\right.$ ) for compounds [2] (top), [3] (middle) and [7] (bottom).

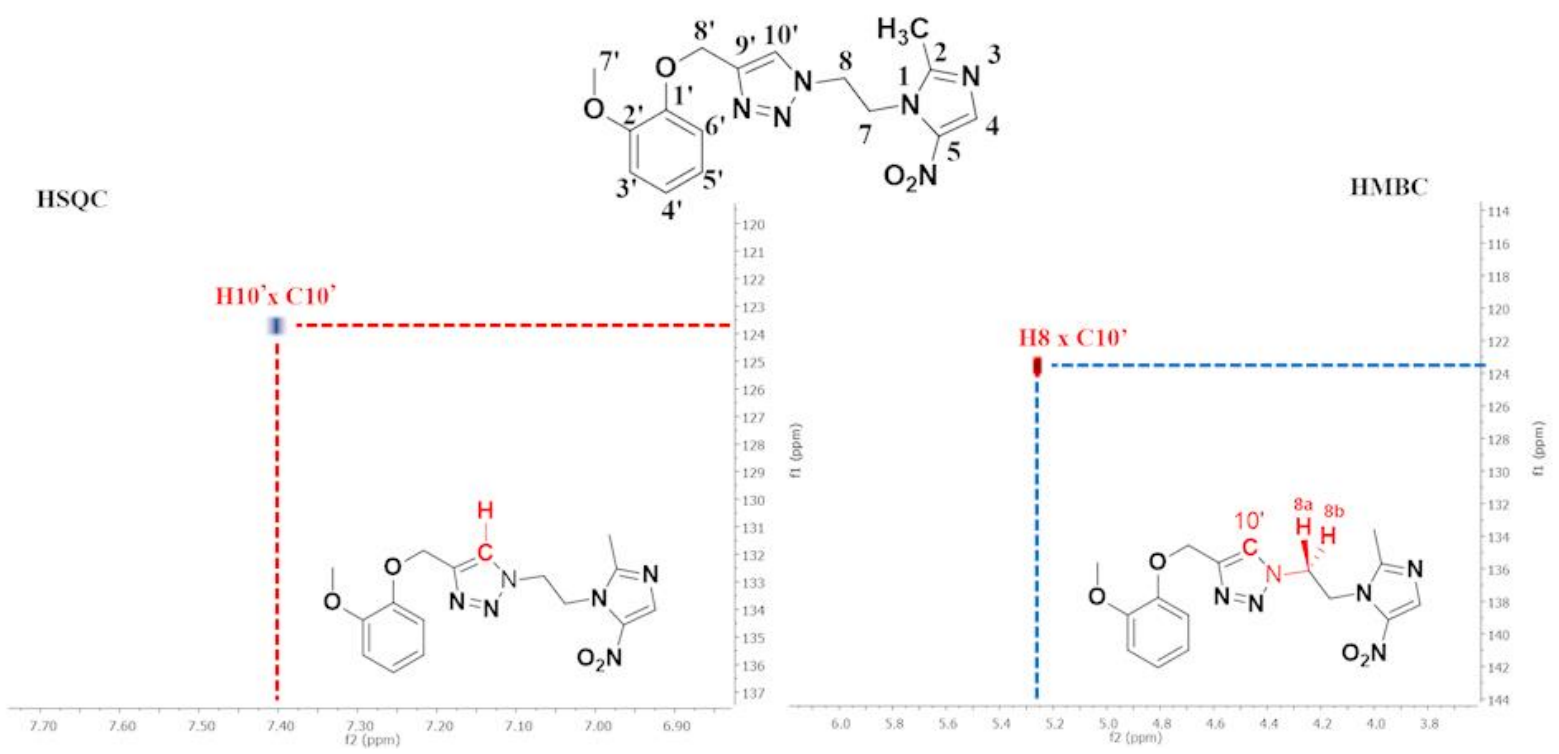

Figure 3. Expanded 2D Spectra ${ }^{1} \mathrm{H}$ NMR (HSQC and $\left.\mathrm{HMBC}\right)\left(300 \mathrm{MHz}, \mathrm{CDCl}_{3}\right)$ of Compound [7].

improvement in antiparasitic action compared to compound [6] with $\mathrm{IC}_{50}$ values of $115 \mu \mathrm{M} \pm 24.6$ $\mu \mathrm{M}, 52 \mu \mathrm{M} \pm 14 \mu \mathrm{M}$ and $33 \mu \mathrm{M} \pm 3 \mu \mathrm{M}$ for compounds [7], [8] and [9] respectively. Obviously, the best result was that from hybrid compound [9] which presents similar activity to the control drug benznidazole $\left(\mathrm{IC}_{50}\right.$ value of 29 $\mu \mathrm{M} \pm 5 \mu \mathrm{M})$.
Testing the hybrids molecules against the Trypomastigote form of $T$. cruzi.

From the results shown in Figure 5, it is possible to observe a pattern similar to the previous assay with compound [6] showing no activity ( $\mathrm{IC}_{50}$ value of $601 \mu \mathrm{M} \pm 1 \mu \mathrm{M})$, and the hybrid compounds showing an improved activity with $\mathrm{IC}_{50}$ values of $110 \mu \mathrm{M} \pm 5 \mu \mathrm{M}, 10 \mu \mathrm{M} \pm 1 \mu \mathrm{M}$ and $17 \mu \mathrm{M} \pm 2 \mu \mathrm{M}$ for compounds [7], [8] and [9] respectively when compared to metronidazole and 
eugenol alone $\left(\mathrm{IC}_{50}\right.$ values of $178 \mu \mathrm{M} \pm 20 \mu \mathrm{M}$ and $160 \mu \mathrm{M} \pm 14 \mu \mathrm{M}$ respectively). For reference, a published $\mathrm{IC}_{50}$ value of $76 \mu \mathrm{g} / \mathrm{ml}$ (no error reported) for eugenol (31) is slightly lower than we obtained, but still relatively comparable. There is a published $\mathrm{IC}_{50}$ value for metronidazole (32) of $1000 \mu \mathrm{M} \pm 164.5 \mu \mathrm{M}$ which is very high in comparison to the results obtained herein (and also very high compared to the published results against the epimastigote form as described in the previous section) leading to the suspicion that those authors may have used a resistant strain. Furthermore, Simões-Silva et al. (33) reported an $\mathrm{EC}_{50}$ value of $>200 \mu \mathrm{M}$ against bloodstream trypomastigotes and an $\mathrm{EC}_{50}$ value $>200 \mu \mathrm{M}$ against amastigotes. Unfortunately, these $\mathrm{EC}_{50}$ values were out of the range of interest for SimõesSilva et al. (33), therefore one cannot accurately speculate how much greater than 200 they were $\mu \mathrm{M}$, but we consider it important to mention them here. It should be noted that in this assay, the activity of hybrid [8] was slightly higher than hybrid [9], and both were the best compounds in this study, presenting activity approaching that of the control drug benznidazole ( $\mathrm{IC}_{50}$ value of $7 \mu \mathrm{M}$ $\pm 1 \mu \mathrm{M})$.

These results give a new insight into the importance of the structural nucleus containing the two units (the metronidazole and eugenol analogue). The results demonstrated that the triazole compound [6] did not show any relevant activity in relation to any of the forms of the parasite tested, which reinforces the importance of the phenolic unit being present. A further observation is that the natural phenolic unit chosen (guaiacol) does not contain the "tail" in the para position, but it was present in the triazole compound [7] which presented the least activity.

\section{Prediction of Toxicity Risk}

The toxicity of drug candidates is a limiting factor in the drug discovery process and its determination is important in the initial stages of a drug design study. In this context, computational methods that support the screening of chemical toxicity risks allow an early and rapid recognition of these properties with low costs $(34,35)$. Using the OSIRIS Property Explorer (27) the physicochemical and toxicological data of metronidazole, eugenol and the hybrid compounds were predicted based upon chemical structure, and structural fragments that may be well-known to have the potential to generate a certain toxic effect (Table 1).

Regarding the toxicological data, despite the well-known and diverse biological activities already demonstrated by both metronidazole and eugenol (resulting in them being used commercially), it is observed that both compounds have specific toxic profiles which would limit them from being used in different situations.

It should be noted that some of the properties calculated by the OSIRIS program (27) (mutagenic, tumorigenic, irritant and reprotoxic properties) do not always match real experiment values and are only used as indicators in early development work. According to the OSIRIS program developers, "Toxicity risk alerts are an indication that the drawn structure may be harmful concerning the risk category specified. However, risk alerts are by no means meant to be a fully reliable toxicity prediction. Nor should be concluded from the absence of risk alerts that a particular substance is completely free of any toxic effect." In general, the results generated by the OSIRIS program are in line with experimental results, but occasionally certain papers highlight results which contradict this. For example, metronidazole is a commercial drug and considered to be safe for its prescribed usage (and the OSIRIS program predicts it is non-mutagenic), however there are several studies which describe metronidazole as having mutagenic properties against bacteria and mammalian cells (36-38).

The predicted parameters for the control drugs are generally in line with published experimental values, which gives confidence in the predicted values for the synthesised hybrid molecules (although obviously full testing would be required as part of the drug approval process). Regarding the predicted values for the synthesised hybrid compounds, the hydroxyl protection of metronidazole appears to reduce its toxic character on the reproductive system, whereas in eugenol, despite reducing its mutagenic effect using the same chemical transformation, the tumorigenic and irritant effects are only modulated with the modification of the allyl chain. From these results, the safest compounds (considering the toxic effects) would be the hybrid compounds [6], [7] and [8]. The low lipophilic nature of compounds [6] and [7] would perhaps make them the compounds with the best conditions to be used in liquid preparations for oral use (for example in a mouthwash). The Drug Score parameter allows us to assess whether the compound has the potential to become a drug by using a single number. The drug score itself is a combined value which is obtained from the druglikeness score, $\operatorname{cLog} \mathrm{P}$ (an indicator for lipophilicity), solubility, molecular indicator for lipophilicity), solubility, molecular mass and toxicological risks into a single value. If 


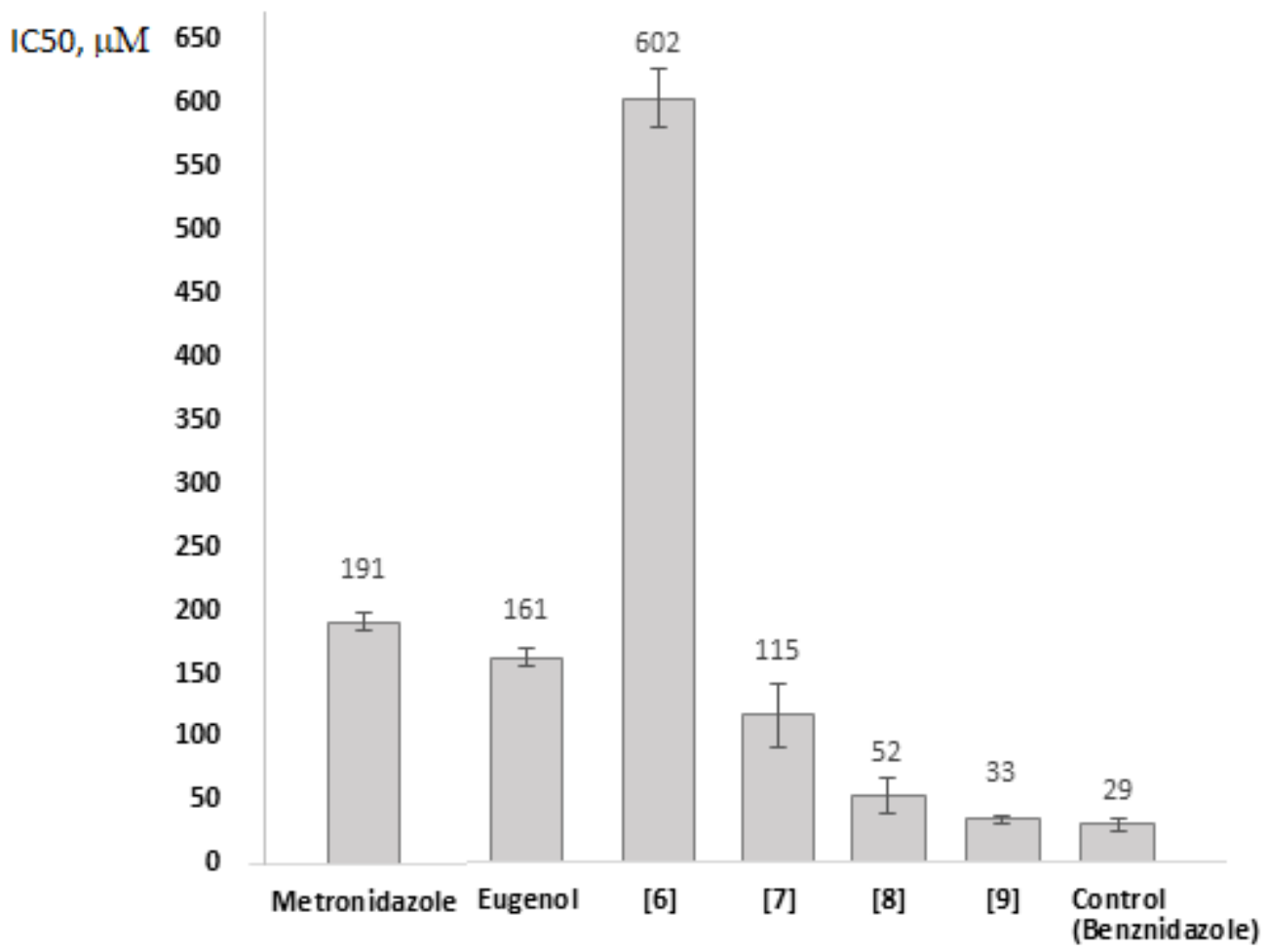

Figure 4. Anti-trypanosomal $\mathrm{IC}_{50}$ values against the epimastigote form of T. cruzi.

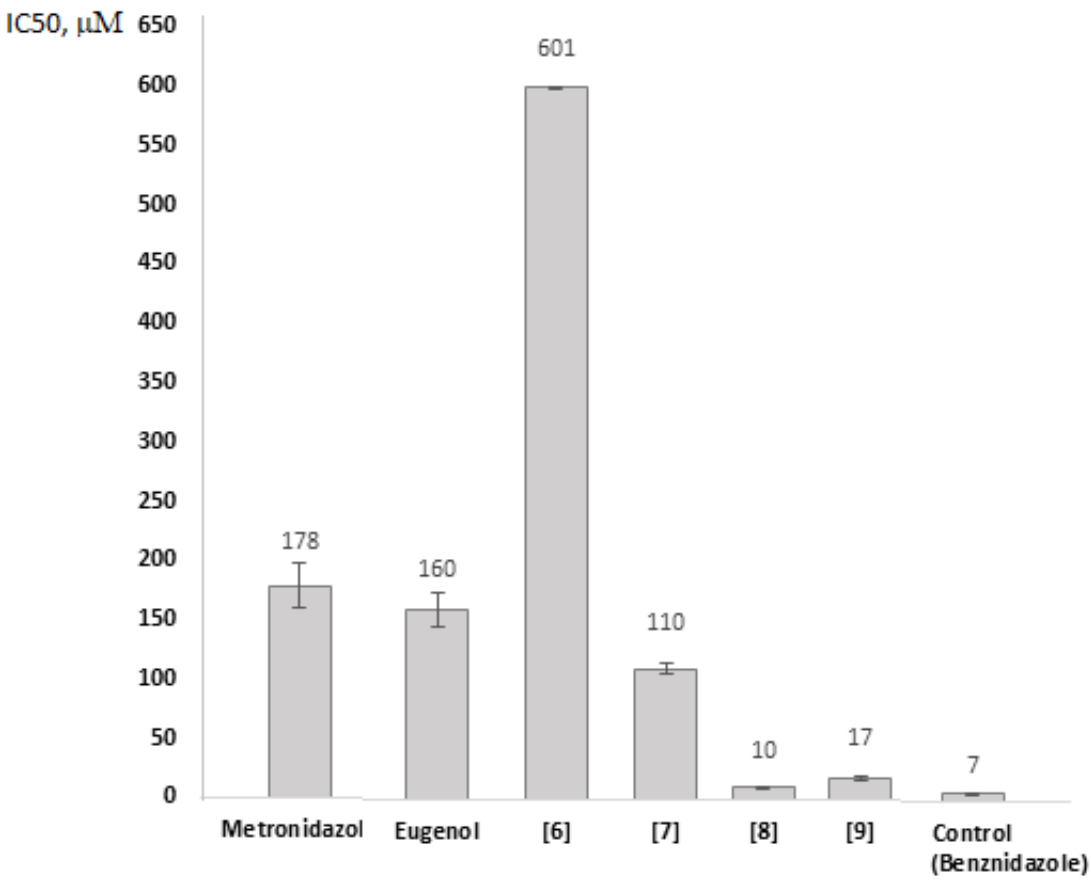

Figure 5. Anti-trypanosomal $\mathrm{IC}_{50}$ values $(\mu \mathrm{M})$ against the trypomastigote form of T. cruzi.

we compare the synthesised hybrid compounds, it is possible to observe that compounds [6] and [7] present Drug Score values close to, or even higher than that observed for the metronidazole drug. These results indicate a great potential for these hybrids to evolve into drugs - when considering only the structural aspects and data provided by the program.
The online "Molinspiration" property calculator (29) allows the calculation of molecular properties from chemical structures. The properties calculated include: GPCR ligand binding, ion channel modulator, kinase inhibitor, nuclear receptor ligand, protease inhibitor \& enzyme inhibitor. Together these calculated properties form the predicted bioactivity score and Table 2 shows theses values for the synthesised compounds along 
with eugenol and metronidazole as comparisons, where the higher values indicate better performance.

It can be seen from these results that the compounds do not have enough structural fragments for the similarity in question to be proposed, since the majority showed negative values regarding the Bioactivity Score or very low positive values. The only compound that showed a Bioactivity Score value that allows the suggestion of a structural similarity to drugs was compound [6] for enzyme inhibitors. It is worth mentioning that the fact that the other compounds do not present such a relationship is not a limitation for them to evolve into drugs. This information only concerns the structural similarity and mechanism of action specified above. This low similarity was already indicated in the forecasts observed in the OSIRIS program (27) as previously mentioned, considering the negative values obtained in that analysis. The pharmacokinetic properties of all hybrid compounds were calculated using the SwissADME database (28) and are shown in Table 3. As the data in Table 3 shows, there is a prediction of high gastrointestinal absorption of the compounds, which could allow their use by the oral route to achieve systemic action. Considering the blood brain barrier (BBB) parameter that indicates the possibility of central action of the compounds, there is a prediction of limited action in this region of the organism, limiting only to the possibility of peripheral action. This characteristic would limit the use of the compounds in diseases that affect the central nervous system, but the possibility of adverse effects would be reduced, if the only peripheral effect of the compound is what is desired. Only hybrid compound [7] was predicted as a P-glycoprotein substrate. One of the main roles of this macromolecule is to act as an efflux pump, its expression being related to many cases of drug resistance (39). In this sense, it can be predicted that with hybrid compound [7] being a substrate of this P-glycoprotein, greater resistance to the treatment of a disease with this compound if $\mathrm{P}$ glycoproteins are present and active. Again, to demonstrate the general reliability of using the OSIRIS program to predict properties, published studies show that metronidazole does not act as a P-glycoprotein substrate (40), and that it can cross the blood brain barrier to access the central nervous system (41), confirming the predicted properties for the controls and giving confidence that the predicted properties for the synthesised hybrids are likely to be reliable.

Regarding the influence of the studied compounds in the inhibition of CYP450 enzymes, there is a prediction of interference in the metabolism of xenobiotics processed by the isoforms CYP1A2, CYP2A19, CYP2C9 and CYP3A4. With the exception of hybrid compound [6], the others could act as inhibitors of at least one of these enzymatic isoforms, thus reducing the metabolism of its substrates. Only the CYP2D6 isoform would not suffer interference from the action of the synthesised triazoles and ethers. The $\mathrm{Kp}$ parameter $(\mathrm{cm} / \mathrm{s})$ consists of the skin permeability coefficient, where the more negative its logarithmic (log Kp) number, the lower the skin permeability of the evaluated compound (42). For comparison against the predicted properties by the SwissADME database, a literature review by Roedler et al. (50) concluded that metronidazole does not inhibit CYP3A4/5 based on controlled in vitro and in vivo studies, although case reports suggest the inhibition. This gives us confidence that the predicted properties for the synthesised hybrids are likely to be reliable.

Table 1. Physicochemical and Toxicological Properties of Synthesised Compounds and Controls

\begin{tabular}{lcccccc}
\hline \multicolumn{1}{c}{ Properties } & \multirow{2}{*}{ Metronidazole } & Eugenol & \multicolumn{5}{c}{ Synthesised Hybrid Compounds } \\
\hline Mutagenic? & No & Yes & No & No & No & No \\
Tumorigenic? & No & Yes & No & No & No & Yes \\
Irritant? & No & Yes & No & No & No & Yes \\
Reprotoxic? & Yes & No & No & No & No & No \\
CLogP & -1.05 & 2.27 & -2.03 & -0.15 & 1.06 & 0.88 \\
Solubility & -0.20 & -2.05 & -0.01 & -1.49 & -2.26 & -2.20 \\
Molecular Mass & 171 & 164 & 252 & 358 & 400 & 398 \\
TPSA & 83.87 & 29.46 & 114.50 & 112.80 & 112.80 & 112.80 \\
Drug-likeness & 0.97 & -2.78 & -2.45 & -1.94 & -3.01 & -3.62 \\
Drug Score & 0.51 & 0.11 & 0.52 & 0.51 & 0.44 & 0.16 \\
\hline
\end{tabular}


Table 2. Calculated Bioactivity Scores for the Synthesised Compounds and Controls.

\begin{tabular}{lcccccc}
\hline \multicolumn{1}{c}{ Properties } & \multirow{2}{*}{ Metronidazole } & \multirow{2}{*}{ Eugenol } & \multicolumn{4}{c}{ Synthesised Hybrid Compounds } \\
& & & {$[6]$} & {$[7]$} & {$[8]$} & {$[$ 9] } \\
\hline GPCR ligand binding & -1.09 & -0.86 & -0.29 & -0.16 & -0.08 & -0.16 \\
Ion channel modulator & -0.87 & -0.36 & -0.33 & -0.32 & -0.27 & -0.30 \\
Kinase inhibitor & -0.59 & -1.14 & -0.07 & 0.04 & -0.03 & -0.10 \\
Nuclear receptor ligand & -1.74 & -0.78 & -1.15 & -0.74 & -0.55 & -0.61 \\
Protease inhibitor & -1.68 & -1.29 & -0.83 & -0.52 & -0.41 & -0.54 \\
Enzyme inhibitor & -0.32 & -0.41 & 0.21 & 0.07 & 0.09 & 0.07 \\
\hline
\end{tabular}

Table 3. Pharmacokinetic Properties

\begin{tabular}{lcccccc}
\hline \multicolumn{1}{c}{ Properties } & \multirow{2}{*}{ Metronidazole } & \multirow{2}{*}{ Eugenol } & \multicolumn{4}{c}{ Synthesised Hybrid Compounds } \\
& & [6] & {$[7]$} & {$[8]$} & {$[9]$} \\
\hline Gastrointestinal Absorption & High & High & High & High & High & High \\
Blood Brain Barrier & No & Yes & No & No & No & No \\
P-glycoproteins (P-gps) & No & No & No & Yes & No & No \\
Inhibition of enzyme CYP1A2 & No & Yes & No & No & No & No \\
Inhibition of enzyme CYP2A19 & No & No & No & Yes & Yes & Yes \\
Inhibition of enzyme CYP2C9 & No & No & No & No & Yes & Yes \\
Inhibition of enzyme CYP2D6 & No & No & No & No & No & No \\
Inhibition of enzyme CYP3A4 & No & No & No & Yes & Yes & Yes \\
Skin permeability coefficient & -7.36 & -5.69 & -8.51 & -7.51 & -6.81 & -6.99 \\
Log Kp $(\mathbf{c m} / \mathbf{s})$ & & & &
\end{tabular}

\section{CONCLUSION}

From the results obtained in this study, we can conclude that hybrid compounds containing a metronidazole unit coupled to natural phenols represent a new class of compounds of therapeutic interest, which should be studied further. In this study we utilised a triazole species as a coupling connector, however exploring other options and their effects on their efficacy is of major importance in further work. There was also increased anti-parasitic activity of the hybrid compounds (against $T$. cruzi) versus the controls with the best result again coming from hybrid compounds [8] and [9] which presents an activity similar to the control drug benznidazole. The new compounds demonstrated an important activity against $T$. cruzi, which is an extremely promising result for new planning of similar structural patterns, as well as the investigation of these compounds against other neglected tropical diseases (NTDs).

\section{CONFLICT OF INTEREST. None.}

ACKNOWLEDGMENTS. This study was financed in part by the Brazilian Federal Agency CAPES (Coordenação de Aperfeiçoamento de Pessoal de Nível Superior Código de
Financiamento 001). The authors also wish to thank the staff in the Laboratory of Clinical \& Experimental Pathology and Parasitology (Laboratório de Patologia e Parasitologia Clínica e experimental) at UNIFAL-MG for maintaining the T. cruzi strai

\section{REFERENCES}

1. Zhang S, Saathoff JM, He L. Chapter 8 Molecular Hybridization: An Emerging Tool for the Design of Novel Therapeutics for Alzheimer's Disease. 2017; 8:219-237. https://doi.org/10.1016/B978-0-08-1010112.00008-8. In: Design of Hybrid Molecules for Drug Development. Editor: Decker M. Elsevier. ISBN: 9780081010112. 2017.

2. Junior CV, Danuello A, Bolzani VS, Barreiro EJ, Fraga CAM. Molecular Hybridization: A Useful Tool in the Design of New Drug Prototypes. Curr Med Chem. 2007; 14:1829-1852. https://doi.org/10.2174/092986707781058805.

3. Wermuth CG, Aldous D, Raboisson P, Rognan D. The Practice of Medicinal Chemistry. Academic Press. London. 2015. $4^{\text {th }}$ Edition. ISBN: 9780124172050.

4. Wright PM, Seiple IB, Myers G. The Evolving Role of Chemical Synthesis in Antibacterial Drug Discovery. Angew Chem Int Ed. 2014; 53:88408869. https://doi.org/10.1002/anie.201310843. 
5. Dunn LA, Burgess AG, Krauger KG, Ekmann L, Vanelle P, Crozette MD, Gillin FD, Upcroft P, Upcroft JA. A New-Generation 5-Nitroimidazole can Induce Highly Metronidazole-Resistant Giardia Lamblia In Vitro. Int J Antimicrob Agents. 2010; 36:37-42. https://doi.org/10.1016/j.ijantimicag.2010.03.004.

6. Oliveira AA, Oliveira APA, Franco LL, Ferencs MO, Ferreira JFG, Bachi SMPS, Speziali NL, Farias LM, Magalhães PP, Beraldo H. 5Nitroimidazole-Derived Schiff Bases and Their Copper (II) Complexes Exhibit Potent Antimicrobial Activity Against Pathogenic Anaerobic Bacteria. Biometals. 2018; 31:571-584. https://doi.org/10.1007/s10534-018-0106-6.

7. Ang CW, Jarrad AM, Cooper MA, Blaskovich MAT. Nitroimidazoles: Molecular Fireworks That Combat a Broad Spectrum of Infectious Diseases. J Med Chem. 2017; 60:7635-7657. https://doi.org/10.1021/acs.jmedchem.7b00143.

8. Marchese A, Barbieri R, Coppo E, Orhan IE, Daglia M, Nabavi SF, Izadi M, Abdollahi M, Nabavi SM, Ajami M. Antimicrobial Activity of Eugenol and Essential Oils Containing Eugenol: A Mechanistic Viewpoint. Crit Ver Microbiol. 2017; 43:668-689.

https://doi.org/10.1080/1040841X.2017.1295225.

9. Hipólito TMM, Bastos GTL, Barbosa TWL, Souza TB, Coelho LFL, Dias ALT, Rodriguez IC, Santos MH, Dias DF, Franco LL, Carvalho DT. Synthesis, Activity, And Docking Studies of Eugenol-Based Glucosides as New Agents Against Candida Sp. Chem Biol Drug Des. 2018; 92:1514-1524. https://doi.org/10.1111/cbdd.13318.

10. Cook GC, Zumla A. Editors. Manson's Tropical Diseases. 22 ${ }^{\text {nd }}$ Edition. Saunders Ltd. 2008. p13271340. ISBN: 9781416044703.

11. Caldas IS, Santos EG, Novaes RD. An Evaluation of Benznidazole as a Chagas Disease Therapeutic. Expert Opin Pharmacother. 2019: 20(15);17971807.

https://doi.org/10.1080/14656566.2019.1650915.

12. Negi B, Raj KK, Siddiqui SM, Ramachandran D, Azam A, Rawat DS. In Vitro Anti-Amoebic Activity Evaluation and Docking Studies of Metronidazole-Triazole Hybrids. Chem Med Chem. 2014; 9:2439-2444. https://doi.org/10.1002/cmdc.201402240.

13. Negi B, Poonan P, Ansari MF, Kumar D, Aggarwal S, Singh R, Azam A, Rawat DS. Synthesis, Anti-Amoebic Activity and Docking Studies of Metronidazole-Triazole-Styryl Hybrids. Eur J Med Chem. 2018; 150:633-641. https://doi.org/10.1016/j.ejmech.2018.03.033.

14. Beena, Kumar N, Rohilla RK, Roy N, Rawat DS. Synthesis and Antibacterial Activity Evaluation of Metronidazole-Triazole Conjugates. Bioorg Med Chem Lett. 2009; 19(5):1396-1398. https://doi.org/10.1016/j.bmcl.2009.01.037.

15. Miyamoto Y, Kalisiak J, Korthals K, Lauwaet T, Cheung DY, Lozano R, Cobo ER, Upcroft P, Upcroft JA, Berg DE, Gillin FD, Fokin VV,
Sharpless KB, Eckmann L. Expanded Therapeutic Potential in Activity Space of Next-Generation 5Nitroimidazole Antimicrobials with Broad Structural Diversity. Proceedings of the National Academy of Sciences 2013; 201302664. https://doi.org/10.1073/pnas.1302664110.

16. Negi B, Kumar D, Kumbukgolla W, Jayaweera S, Ponnan P, Singh R, Agarwal S, Rawat DS. AntiMethicillin Resistant Staphylococcus Aureus Activity, Synergism with Oxacillin and Molecular Docking Studies of Metronidazole-Triazole Hybrids. Eur J Med Chem. 2016; 115:426-37. https://doi.org/10.1016/j.ejmech.2016.03.041.

17. Fokin V, Sharpless KB, Eckmann L, Miyamoto Y. Expanded Therapeutic Potential in Nitro Heteroaryl Antimicrobials. From PCT Int Appl. (2014) WO2014205414. Espacenet database.

18. Kolb HC, Finn MG, Sharpless KB. Click Chemistry: Diverse Chemical Function from a Few Good Reactions. Angewandte Chemie Int Ed Engl. 2001; 40(11):2004-2021. https://doi.org/10.1002/15213773(20010601)40:11<2004::aidanie2004>3.3.co;2-x.

19. Jiang X, Hao X, Jing L, Wu H, Kang D, Liu X, Zhan P. Recent Applications of Click Chemistry in Drug Discovery. Expert Opinion on Drug Discovery. $\quad 2019 ; \quad 14: 779-789$. https://doi.org/10.1080/17460441.2019.1614910.

20. Ottoni FM, Gomes ER, Pádua RM, Oliveira MC, Silva IT, Alves RJ. Synthesis and Cytotoxicity Evaluation of Glycosidic Derivatives of Lawsone Against Breast Cancer Cell Lines. Bioorg Med Chem Lett. 2020; 30(2):126817. https://doi.org/10.1016/j.bmcl.2019.126817.

21. Almeida RG, Valença WO, Rosa LG, Simone CA, Castro SL, Barbosa JMC, Pinheiro DP, Paier CRK, Carvalho GGC, Pessoa C, Goulart MOF, Kharma A, Júnior ENS. Synthesis of Quinone Imine and Sulphur-Containing Compounds with Antitumor and Trypanocidal Activities: Redox and Biological Implications. Eur J Org Chem. 2020; 11:11451160. https://doi.org/10.1039/D0MD00072H.

22. Junior EFC, Guimarães CFRC, Franco LL, Alves RJ, Kato KC, Martins HR, Filho JDS, Bemquerer MP, Munhoz VHO, Resende JM, Verly RM. Glycotriazole-Peptides Derived from The Peptide HSP1: Synergistic Effect of Triazole and Saccharide Rings on The Antifungal Activity. Amino Acids. 2017; 49:1389-1400. https://doi.org/10.1007/s00726-017-2441-2.

23. World Health Organization website. www.who.int/neglected_diseases/diseases/en/ Accessed on 17/07/2020.

24. Mazzeti AL, Diniz LDF, Gonçalves KR, WonDollinger RS, Assíria T, Ribeiro I, Bahia MT. Synergic Effect of Allopurinol in Combination with Nitroheterocyclic Compounds Against Trypanosoma cruzi. Antimicrob Agents Chemother. 2019; 63:e02264-18. https://doi.org/10.1128/AAC.02264-18. 
25. Simões-Silva MR, De Araújo JS, Peres RB, Da Silva PB, Batista MM, De Azevedo LD, Bastos MM, Bahia MT, Boechat N, Soeiro MNC. Repurposing Strategies for Chagas Disease Therapy: The Effect of Imatiniband Derivatives Against Trypanosoma cruzi. Parasitology. 2019; 146:1006-1012.

https://doi.org/10.1017/S0031182019000234.

26. Gonçalves-Santos E, Vilas-Boas DF, Diniz LF, Veloso MP, Mazzeti AL, Rodrigues MR, Oliveira CM, Fernandes VHC, Novaes RD, Chagas-Paula DA, Caldas IS. Sesquiterpene Lactone Potentiates the Immunomodulatory, Antiparasitic and Cardioprotective Effects on Anti-Trypanosoma cruzi Specific Chemotherapy. Int Immunopharmacol. 2019; 77:105961. https://doi.org/10.1016/j.intimp.2019.105961.

27. OSIRIS Property Explorer. Available online: www.organic-chemistry.org/prog/peo/. Accessed 01/07/2021.

28. Swiss Institute of Bioinformatics SwissADME online database. www.swissadme.ch. Accessed 01/07/2021.

29. Molinspiration Property Calculator Program. Available online: www.molinspiration.com. Accessed 01/07/2021.

30. Spectrometric Identification of Organic Compounds, $7^{\text {th }}$ Edition. 2005. Eds: Silverstein RM, Webster FX, Kiemle D. Wiley. ISBN: 1118311655 .

31. Santoro GF, Cardoso MG, Guimarães LGL, Mendonça LZ, Soares MJ. Trypanosoma cruzi: Activity of Essential Oils from Achillea Millefolium L., Syzygium aromaticum L. and Ocimum basilicum L. on Epimastigotes and Trypomastigotes. Exp Parasitol. 2007; 116(3):283-290.

https://doi.org/10.1016/j.exppara.2007.01.018.

32. Lopes M, Sales P, Lopes A, Yoshida M, Silva T, Romanha AJ, Alves R, Oliveira R. The Activity of a Metronidazole Analogue and its B-Cyclodextrin Complex Against Trypanosoma cruzi. Memórias do Instituto Oswaldo Cruz. 2011; 106(8):1055$1057 . \quad$ https://doi.org/10.1590/S007402762011000800027.

33. Simões-Silva MR, De Araújo JS, Oliveira GM, Demarque KC, Peres RB, D'Almeida-Melo I, Batista DGJ, Da Silva CF, Cardoso-Santos C, Da Silva PB, Batista MM, Bahia MT. Drug Repurposing Strategy Against Trypanosoma cruzi Infection: In Vitro and In Vivo Assessment of The Activity of Metronidazole in Mono- and Combined Therapy. Biochem Pharmacol. 2017; 145:46-53.

https://doi.org/10.1016/j.bcp.2017.08.025.

34. Roncaglioni A, Toropov AA, Toropova AP, Benfenati E. In Silico Methods to Predict Drug
Toxicity. Curr Opin Pharmacol. 2013; 13 (5):802806. https://doi.org/10.1016/j.coph.2013.06.001.

35. Raies AB, Bajic VB. In Silico Toxicology: Computational Methods for the Prediction of Chemical Toxicity. Wiley Interdiscip Rev Comput Mol Sci. 2016; 6(2):147-172. https://doi.org/10.1002/wcms.1240.

36. Comprehensive Guide to the RTECS. 1997; Publication No. 97-119. Registry of Toxic Effects of Chemical Substances (RTECS). The National Institute for Occupational Safety and Health (NIOSH) \& the US Department of Health (DHHS). Available online: https://www.cdc.gov/niosh/docs/97-

119/default.html. Accessed 27 July 2021.

37. Buschini A, Ferrarini L, Franzoni S, Galati S, Lazzaretti M, Mussi F, Northfleet de Albuquerque C, Zucchi TMAD, Poli P. Genotoxicity Revaluation of Three Commercial Nitroheterocyclic Drugs: Nifurtimox, Benznidazole, and Metronidazole. J Parasitol Res. 2009; 2009:463575. https://doi.org/10.1155/2009/463575.

38. Bendesky A, Menéndez D, Ostrosky-Wegman P. Is Metronidazole Carcinogenic? Mutat Res. 2002; 511(2):133-44. https://doi.org/10.1016/s1383$\underline{\text { 5742(02)00007-8. }}$

39. Chen L, Li Y, Yu H, Zhang L, Hou T. Computational Models for Predicting Substrates or Inhibitors of P-Glycoprotein. Drug Discov Today. 2012; 17(7-8):343-51. https://doi.org/10.1016/j.drudis.2011.11.003.

40. Tan SY, Kan E, Lim WY, Chay G, Law JHK, Soo GW, Bukhari NI, Segarra I. Metronidazole Leads to Enhanced Uptake of Imatinib in Brain, Liver and Kidney Without Affecting its Plasma Pharmacokinetics in Mice. J Pharm Pharmacol. 2011;

63(7):918-925.

https://doi.org/10.1016/10.1111/j.2042-

7158.2011.01296.x.

41. Nau R, Sörgel F, Eiffert H. Penetration of Drugs Through the Blood-Cerebrospinal Fluid/BloodBrain Barrier for Treatment of Central Nervous System Infections. Clin Microbiol Rev. 2010; 23(4):858-883.

https://doi.org/10.1128/CMR.00007-10.

42. Potts RO, Guy RH. Predicting Skin Permeability. Pharm Res. 1992; 9(5):663-669. https://doi.org/10.1023/A:1015810312465.

43. Roedler R, Neuhauser MM, Penzak SR. Does Metronidazole Interact with CYP3A Substrates by Inhibiting Their Metabolism Through This Metabolic Pathway? Or Should Other Mechanisms be Considered? Ann Pharmacother. 2007; 41(4):653-658.

https://doi.org/10.1345/aph.1H401. 